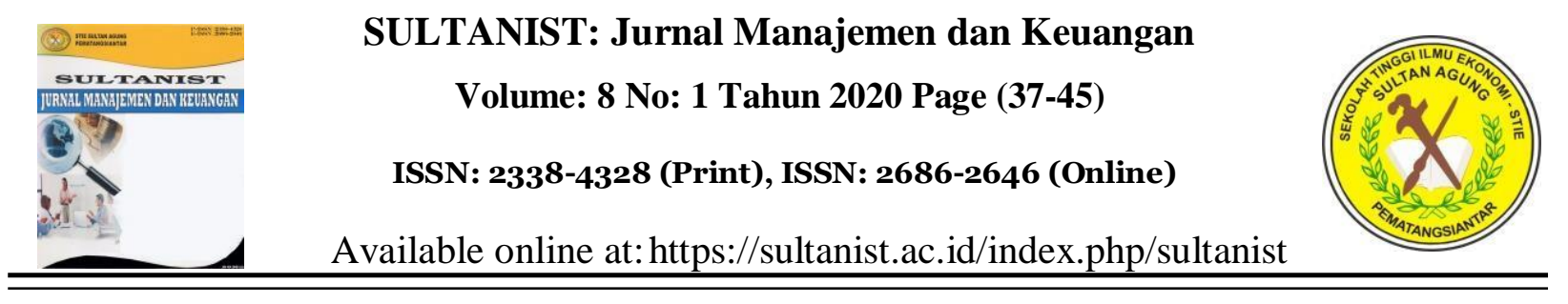

\title{
PENGARUH KECERDASAN SPIRITUAL DAN KECERDASAN EMOSIONAL TERHADAP KINERJA PEGAWAI BADAN NARKOTIKA NASIONAL PEMATANGSIANTAR
}

\author{
Aufiar Riesvi ${ }^{1}$, Darwin Lie $^{2}$, Efendi ${ }^{3}$, Sherly ${ }^{4}$ \\ Program Studi Manajemen, Sekolah Tinggi Ilmu Ekonomi Sultan Agung \\ aufiarriesvi@gmail.com \\ Program Studi Manajemen, Sekolah Tinggi Ilmu Ekonomi Sultan Agung \\ darwin@stiesultanagung.ac.id, efendi@stiesultanagung.ac.id, sherly@stiesultanagung.ac.id
}

\begin{abstract}
Abstrak
Tujuan penelitian ini adalah: Untuk mengetahui gambaran kecerdasan spiritual, kecerdasan emosional, dan kinerja pegawai pada Badan Narkotika Nasional Pematangsiantar. Untuk mengetahui pengaruh kecerdasan spiritual dan kecerdasan emosional terhadap kinerja pegawai pada Badan Narkotika Nasional Pematangsiantar baik secara simultan maupun parsial. Hasil penelitian dapat disimpulkan sebagai berikut: Kecerdasan spiritual, kecerdasan emosional dan kinerja pegawai sudah baik. Kecerdasan spiritual dan kecerdasan emosional berpengaruh positif terhadap kinerja pegawai. Kecerdasan spiritual dan kecerdasan emosional memiliki hubungan yang kuat dan positif dengan kinerja pegawai. Kemudian baik tidaknya kinerja pegawai dapat dijelaskan oleh kecerdasan spiritual dan kecerdasan emosional. 4. Hasil uji hipotesis menyatakan H0 ditolak, artinya kecerdasan spiritual dan kecerdasan emosional berpengaruh positif dan signifikan terhadap kinerja pegawai baik secara simultan maupun parsial.
\end{abstract}

Kata kunci: Kecerdasan Spiritual, Kecerdasan Emosional, dan Kinerja Pegawai

\section{THE EFFECT OF SPIRITUAL INTELLIGENCE AND EMOTIONAL INTELLIGENCE ON THE PERFORMANCE OF EMPLOYEE NATIONAL NARCOTICS AGENCY IN PEMATANGSIANTAR}

\begin{abstract}
The purpose of this research is: To determine the description of spiritual intelligence, emotional intelligence, and employee performance at Badan Narkotika Nasional Pematangsiantar. To determine the effect of spiritual intelligence and emotional intelligence on employee performance at Badan Narkotika Nasional Pematangsiantar both simultaneously and partially. Result of the study can be summerized as follows: Spiritual intelligence, emotional intelligence and employee performance are good. Spiritual intelligence and emotional intelligence have positive effect on employee performance. Spiritual intelligence and emotional intelligence have moderately high and positive correlation with employee performance. Hypothesis test results state that $H_{0}$ is rejected, meaning that spiritual intelligence and emotional intelligence have positive and significant effect on employee performance both simultaneously and partially.
\end{abstract}

Keywords: Spiritual Intelligence, Emotional Intelligence, and Employee Performance 


\section{PENDAHULUAN}

Keberhasilan dalam suatu organisasi tergantung dari sumber daya manusia yang mendukung kegiatan operasional organisasi tersebut. Ini dikarenakan sumber daya manusia merupakan suatu aset yang paling berharga yang dimiliki oleh suatu organisasi atau perusahaan. Oleh sebab itu, banyak organisasi yang selalu berusaha meningkatkan kualitas sumber daya manusia.

$$
\text { Badan Narkotika Nasional }
$$

Pematangsiantar merupakan salah satu badan yang melaksanakan pencegahan dan pemberantasan atas penyalahgunaan dan peredaran gelap narkotika, psikotropika dan bahan adiktif lainnya (P4GN) berdasarkan Peraturan Presiden Nomor 23 Tahun 2010. Badan Narkotika Nasional Pematangsiantar berlokasi di Jalan Keselamatan No. 7 Kelurahan Suka Dame, Kecamatan Siantar Utara, Kota Pematangsiantar. Badan Narkotika Nasional Pematangsiantar memerlukan kinerja pegawai yang baik untuk dapat mewujudkan pelayanan yang optimal khususnya dalam menjalankan tugas dan tanggung jawabnya.

Kinerja pegawai merupakan hasil kerja yang dicapai oleh pegawai dalam melaksanakan tugasnya sesuai standar organisasi yang telah ditetapkan Badan Narkotika Nasional Pematangsiantar. Kinerja pegawai pada Badan Narkotika Nasional Pematangsiantar diatur dalam PP No. 46 Tahun 2011 yaitu Sasaran Kerja Pegawai (SKP) terdiri dari kuantitas, kualitas, waktu dan biaya, serta Perilaku Kerja (PK) yang terdiri dari orientasi pelayanan, integrasi, komitmen, disiplin, kerja sama dan kepemimpinan. Berikut ini adalah fenomena kinerja dari Pegawai Negeri Sipil (PNS) pada Badan Narkotika Nasional Pematangsiantar.

Fenomena kecerdasan spiritual pada Badan Narkotika Nasional Pematangsiantar terlihat pada dimensi jalan pengasuhan, dimana masih ada pegawai yang kurang memberi pembelajaran dan masukan kepada pegawai yang lain dalam melaksanakan tugasnya. Pada dimensi jalan pengetahuan, terlihat pada pegawai masih ada pegawai yang menunggu-nunggu informasi langsung tanpa mencari tau ada atau tidaknya informasi yang berkaitan dengan pekerjaannya. Selain itu, faktor lain yang mempengaruhi kinerja adalah kercerdasan emosional. Menurut Goleman (2005), "kecerdasan emosional adalah kemampuan memantau dan mengendalikan perasaan tersebut untuk memadu pikiran dan tindakan sehingga kecerdasan emosional sangat diperlukan dalam melakukan tugasnya dan dapat menghasilkan kinerja yang jauh lebih baik dalam pekerjaannya". Adapun dimensi kecerdasan emosional yaitu kesadaran diri, pengaturan diri, motivasi, empati, dan keterampilan sosial.

Fenomena kecerdasan emosional pada Badan Narkotika Nasional Pematangsiantar terlihat pada dimensi kesadaran diri, dimana ada beberapa pegawai yang belum sepenuhnya mengenali kelemahan sendiri sehingga kurang cekatan dalam melakukan pekerjaannya. Kemudian pada dimensi pengaturan diri, dimana pegawai masih optimal dalam mengendalikan emosi baik itu masalah pekerjaan ataupun masalah pribadi. Dan pada dimensi motivasi, dimana pegawai masih kurang efektif dalam bekerja sehingga pegawai sering menghadapi kemunduran dalam menyelesaikan pekerjaannya. Tujuan penelitian ini antara lain untuk mengetahui gambaran kecerdasan spiritual, kecerdasan emosional, dan kinerja pegawai pada Badan Narkotika Nasional Pematangsiantar dan untuk mengetahui pengaruh kecerdasan spiritual dan kecerdasan emosional terhadap kinerja pegawai pada Badan Narkotika Nasional Pematangsiantar baik secara simultan maupun parsial.

\section{LANDASAN TEORI}

\section{Kecerdasan Spiritual}

Menurut Khavari (2004), kecerdasan spiritual sebagai fakultas dimensi non-material kita atau jiwa manusia. Ia menyebutnya sebagai intan yang belum terasah dan dimiliki oleh semua insan. Manusia harus mengenali seperti adanya lalu menggosoknya sehingga mengkilap dengan tekad yang besar, menggunakannya menuju kearifan, dan untuk mencapai kebahagiaan yang abadi. Selanjutnya pendapat Zohar dan Ian (2000), kecerdasan spiritual adalah kecerdasan untuk menghadapi 
persoalan makna atau value, yaitu kecerdasan untuk menempatkan perilaku dan hidup kita dalam konteks makna yang lebih luas dan kaya, kecerdasan untuk menilai bahwa tindakan atau jalan hidup seseorang lebih bermakna dibandingkan orang lain. Menurut Agustian (2001), kecerdasan spiritual adalah kecerdasan yang meliputi emosi dan spiritual dengan konsep universal yang mampu menghantarkan pada predikat memuaskan bagi dirinya dan orang lain, serta dapat menghambat segala hal yang kontradiktif terhadap kemajuan umat manusia.

\section{Kecerdasan Emosional}

Menurut Robbins dan Timothy (2009), kecerdasan emosi adalah kemampuan seseorang untuk mendeteksi serta mengolah petunjuk-petunjuk dan informasi emosional. Menurut Goleman (2005), kecerdasan emosional adalah dorongan untuk bertindak, rencana seketika untuk mengatasi masalah yang telah ditanamkan secara berangsurangsur (evolusi), dan emosi juga sebagai perasaan dan juga fikiran-fikiran khas, suatu keadaan biologis dan psikologi serta serangkaian kecendrungan untuk bertindak. Sedangkan menurut Agustian (2001), "kecerdasan emosional mengatakan bahwa orang yang memiliki kecerdasan otak saja (IQ) atau orang yang memiliki gelar tinggi belum tentu sukses berkiprah di dunia kerja atau lebih buruk lagi tersingkir diakibatkan rendahnya kecerdasan emosi dan hati mereka. Dan menyimpulkan bahwa kecerdasan emosional adalah kunci utama kecerdasan seseorang.

\section{Kinerja Pegawai}

Menurut Bangun (2012), "kinerja adalah hasil pekerjaan yang dicapai seseorang berdasarkan persyaratan-persyaratan pekerjaan (job requirement)". Menurut Mathis dan John (2006), "kinerja adalah suatu hasil kerja yang dicapai seseorang dalam melaksanakan tugas-tugas yang dibebankan kepadanya yang disarankan atas pengalaman, kesungguhan, kecakapan serta waktu". Sedangkan menurut Mangkunegara (2015:67), "kinerja adalah hasil kerja secara kualitas dan kuantitas yang dicapai oleh seorang pegawai dalam melaksanakan tugasnya sesuai dengan tanggung jawabnya sesuai dengan yang diberikan kepadanya". Berdasarkan uraian di atas, penulis menyimpulkan bahwa kinerja adalah hasil kerja yang dicapai seseorang dalam melaksanakan tugas-tugas yang dibebankan kepadanya yang disarankan atas pengalaman, kesungguhan, kecakapan serta waktu.

\section{METODE PENELITIAN}

Dalam penelitian ini, penulis menggunakan desain penelitian kepustakaan dan lapangan. Objek penelitian adalah pegawai Badan Narkotika Nasional Pematangsiantar, tempat penelitian dilakukan pada Badan Narkotika Nasional Pematangsiantar. Jenis data yang digunakan adalah data kualitatif dan kuantitatif dan sumber data berasal dari data primer dan data sekunder. Data penelitian dikumpulkan dengan melakukan wawancara, dokumentasi dan penyebaran kuesioner. Analisis data meliputi analisis data kualitatif dan analisis kuantitatif.

\section{PEMBAHASAN}

\section{Analisis Deskriptif Kualitatif}

Analisis deskriptif dimaksudkan untuk mendapatkan gambaran komunikasi interpersonal, kompensasi terhadap kepuasan kerja karyawan pada PT Perkebunan Nusantara III (Persero) Kebun Bangun. Adapun penetapan kriteria nilai rata-rata jawaban responden tersebut dimasukkan ke dalam kelas-kelas interval berikut:

Tabel 1. Nilai Interval dan Kategori Jawaban Responden

\begin{tabular}{|c|c|}
\hline $\begin{array}{c}\text { Nilai } \\
\text { interval }\end{array}$ & Kategori \\
\hline $1,00-1,80$ & $\begin{array}{c}\text { Sangat Tidak Baik/ Sangat Tidak } \\
\text { Puas }\end{array}$ \\
\hline $1,81-2,60$ & Tidak Baik/Tidak Puas \\
\hline $2,61-3,40$ & Cukup Baik/Cukup Puas \\
\hline $3,41-4,20$ & Baik/Puas \\
\hline $4,21-5,00$ & Sangat Baik/Sangat Puas \\
\hline
\end{tabular}

Sumber: hasil pengolahan data (2019) 
Gambaran Kecerdasan Spiritual Pada Badan Narkotika Nasional Pematangsiantar

Dari total jawaban responden mengenai kecerdasan spiritual mendapat nilai rata-rata sebesar 3,76 dengan kriteria jawaban baik. Kemudian nilai rata-rata tertinggi sebesar 4,28 dengan kriteria jawaban sangat baik untuk dimensi jalan persaudaraan pada indikator bersikap membangun persaudaraan. Sedangkan nilai rata-rata terendah sebesar 3,12 dengan kriteria jawaban cukup baik untuk dimensi jalan pengasuhan pada indikator membangun rasa saling melindungi rekan kerja.

\section{Gambaran Kecerdasan Emosional Pada

Badan Narkotika Nasional
Pematangsiantar

Secara keseluruhan total jawaban responden mengenai kecerdasan emosional mendapat nilai rata-rata sebesar 3,78 dengan kriteria jawaban baik. Kemudian nilai ratarata tertinggi sebesar 4,20 dengan kriteria jawaban baik untuk dimensi empati pada indikator menyesuaikan diri dengan baik, dan pada dimensi keterampilan sosial dengan indikator menciptakan hubungan yang harmonis dan memberikan respon baik terhadap lawan bicara. Sedangkan nilai ratarata terendah sebesar 3,12 dengan kriteria jawaban cukup baik dimensi kesadaran diri pada indikator mengenali perasaan diri sendiri, pada dimensi pengaturan diri untuk indikator mampu menangani emosi diri sendiri, dan pada dimensi motivasi untuk indikator dorongan untuk mencapai tujuan.

\section{Gambaran Kinerja Pegawai Pada Badan Narkotika Nasional Pematangsiantar}

Dari total jawaban responden mengenai kinerja pegawai mendapat nilai rata-rata sebesar 3,89 dengan kriteria jawaban baik. Kemudian nilai rata-rata tertinggi sebesar 4,28 dengan kriteria jawaban sangat baik untuk dimensi sasaran kerja pegawai pada indikator tingkat efisiensi waktu pada dimensi perilaku kerja dengan indikator tingkat kepatuhan terhadap peraturan. Sedangkan nilai rata-rata terendah sebesar 3,12 dengan kriteria jawaban cukup baik untuk dimensi sasaran kerja pegawai dengan indikator ketepatan waktu menyelesaikan pekerjaan dan pada dimensi perilaku kerja dengan indikator mengutamakan kepentingan dinas di atas kepentingan pribadi.

\section{Analisis Deskriptif Kuantitatif}

\section{Analisis Regresi Linier Berganda}

Penelitian ini memiliki tujuan untuk menganalisis pengaruh kecerdasan spiritual dan kecerdasan emosional terhadap kinerja pegawai. Dalam penelitian ini untuk analisis data menggunakan analisis regresi linier berganda. Analisis regresi linier berganda digunakan untuk mengetahui pengaruh variabel bebas $(\mathrm{X})$ dan variabel terikat $(\mathrm{Y})$, dimana $\mathrm{X}$ adalah kecerdasan spiritual dan kecerdasan emosional, lalu $\mathrm{Y}$ adalah kinerja pegawai. Maka dilakukan perhitungan menggunakan program aplikasi SPSS versi 21 dengan hasil hitung regresi sebagai berikut:

Tabel 2. Hasil Regresi Linear Berganda

\begin{tabular}{|l|l|r|r|}
\hline \multirow{2}{*}{ Model } & \multicolumn{2}{|l|}{$\begin{array}{l}\text { Unstandardized } \\
\text { Coefficients }\end{array}$} & $\begin{array}{l}\text { Standardized } \\
\text { Coefficients }\end{array}$ \\
\cline { 2 - 5 } & \multicolumn{1}{c|}{ B } & Std. Error & \multicolumn{1}{c|}{ Beta } \\
\hline 1 & 1.778 & 12.209 & \\
\hline $\begin{array}{l}\text { (Constant) } \\
\begin{array}{l}\text { Kecerdasan } \\
\text { Spiritual }\end{array}\end{array}$ &, 620 &, 212 &, 481 \\
\cline { 2 - 5 } $\begin{array}{l}\text { Kecerdasan } \\
\text { Emosional }\end{array}$ &, 594 &, 247 &, 395 \\
\hline
\end{tabular}

a. Dependent Variable: Kinerja Pegawai

Sumber: hasil pengolahan data (2019)

Dari hasil analisis regresi dengan SPSS diperoleh model persamaan $\hat{\mathrm{Y}}=1,778+$ $0,620 X_{1}+0,594 X_{2}$, artinya adanya pengaruh positif antara kecerdasan spiritual dan kecerdasan emosional terhadap kinerja pegawai pada Badan Narkotika Nasional Pematangsiantar.

\section{Analisis Korelasi dan Koefisien Determinan (KD)}

Untuk Analisis distribusi frekuensi jawaban responden menurut skor dari variabel $\mathrm{X}_{1} \quad$ (kecerdasan spiritual), $\mathrm{X}_{2}$ (kecerdasan emosional) dan Y (kinerja pegawai) dimaksud sebagaimana telah dilakukan, hanyalah bermanfaat untuk memberikan informasi pendahuluan 
mengenai pola distribusi jawaban responden menurut skor. Selanjutnya dilakukan perhitungan korelasi berupa derajat atau kedalaman hubungan fungsional yang menjelaskan hubungan antara perubah yang dinamakan korelasi yang sering disimbolkan dengan Nilai $r$ dapat dihitung menggunakan SPSS Versi 21. Hasil korelasi dan koefisien determinasi dapat dilihat pada tabel berikut ini:

Tabel 3. Koefisien Korelasi dan Koefisien Determinasi

\begin{tabular}{|c|c|c|c|c|}
\hline Model & $\mathbf{R}$ & \begin{tabular}{|c|}
$\mathbf{R}$ \\
Square
\end{tabular} & $\begin{array}{l}\text { Adjusted } \\
\text { R Square }\end{array}$ & Std. Error of the Estimate \\
\hline 1 & $.793^{\mathrm{a}}$ & .628 & .596 & 59875 \\
\hline
\end{tabular}

Sumber: hasil pengolahan data (2019)

Dari tabel 3, diperoleh nilai $\mathrm{r}=0,793$ yang artinya terdapat hubungan yang kuat dan positif antara kecerdasan spiritual dan kecerdasan emosional dengan kinerja pegawai pada Badan Narkotika Nasional Pematangsiantar. Kemudian diperoleh nilai koefisien determinasi $\mathrm{R}=0,628$ artinya baik tidaknya kinerja pegawai pada Badan Narkotika Nasional Pematangsiantar sebesar $62,8 \%$ dapat dijelaskan oleh kecerdasan spiritual dan kecerdasan emosional, sedangkan sisanya sebesar $37,2 \%$ dipengaruhi oleh faktor lain seperti budaya organisasi, kompetensi pegawai, prestasi kerja dan variabel lain yang tidak diteliti dalam penelitian ini.

\section{Uji Hipotesis}

Pengujian ini dilakukan secara simultan yaitu dilakukan untuk menentukan diterima atau ditolaknya hipotesis, pengujian hipotesis dilakukan untuk mengetahui apakah variabel kecerdasan spiritual dan kecerdasan emosional yang di uji berpengaruh terhadap kinerja pegawai, jika $\mathrm{F}_{\text {hitung }}>\mathrm{F}_{\text {tabel }}$ signifikan $\leq 0,05$ maka $\mathrm{H}_{0}$ ditolak. Dengan menggunakan bantuan program SPSS versi 21, didapatkan hasil

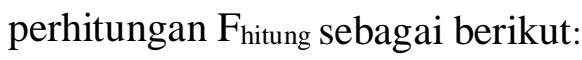

Tabel 4. Perkiraan Nilai $F_{\text {hitung }}$

\begin{tabular}{|c|c|c|c|}
\hline Model & $\begin{array}{c}\text { Sum of } \\
\text { Squares }\end{array}$ & F & Sig \\
\hline Regression & 1393.991 & $\mathbf{1 9 . 4 4 4}$ & $\mathbf{. 0 0 0}^{\mathbf{b}}$ \\
\hline Residual & 824.471 & & \\
\hline Total & 2218.462 & & \\
\hline
\end{tabular}

a. Dependent Variable: Kinerja Pegawau

b. Predictors: (Constant), Kecerdasan Spritiual, Kecerdasan Emosional

Sumber: hasil pengolahan data (2019)

Berdasarkan tabel 4, Berdasarkan tabel 4, di atas diperoleh nilai $F_{\text {hitung }}$ sebesar 19,444 $>\mathrm{F}_{\text {tabel }}$ dengan $(0,05 ; 2$ vs 23$)$ sebesar 3,42 atau dengan signifikanSI $0,000<\alpha 0,05$ maka $\mathrm{H}_{0}$ ditolak, artinya kecerdasan spiritual dan kecerdasan emosional berpengaruh positif dan signifikan terhadap kinerja pegawai pada Badan Narkotika Nasional Pematangsiantar.

Pengujian selanjutnya adalah uji t. Pengujian ini dilakukan secara parsial yaitu untuk menentukan diterima atau ditolaknya hipotesis, pengaruh hipotesis dilakukan untuk mengetahui apakah vvariabel kecerdasan spiritual dan kecerdasan emosional yang di uji berpengaruh terhadap kinerja pegawai, jika $t_{\text {hitung }}>t_{\text {tabel }}$ signifikan $\alpha \leq 0,05$ maka $\mathrm{H}_{0}$ ditolak. Untuk menguji kebenarannya maka dilakukan pengujian hipotesis dengan menggunakan program SPSS versi 21.

Tabel 5. Perkiraan nilai $\boldsymbol{t}_{\text {hitung }}$

\begin{tabular}{|c|c|c|}
\hline \multicolumn{3}{|c|}{ Coefficients $^{\boldsymbol{a}}$} \\
\hline Model & $\mathrm{t}$ & Sig \\
\hline Constant & 4.556 & \\
\hline Kecerdasan Spiritual & $\mathbf{2 . 9 4 2}$ & $\mathbf{0 . 0 0 0}$ \\
\hline Kecerdasan Emosional & $\mathbf{3 . 2 0 7}$ & $\mathbf{0 . 0 0 0}$ \\
\hline
\end{tabular}

Sumber: hasil pengolahan data (2019)

Dari tabel 5, dapat dilihat di atas diperoleh nilai thitung pada variabel $X_{1}$ (kecerdasan spiritual) sebesar 2,925 $>t_{\text {tabel }}$ dengan $\mathrm{df}=\mathrm{n}-\mathrm{k}-1(26-2-1=23)$ sebesar 2,06866 atau taraf signifikansi $0,008<\alpha 0,05$ maka $\mathrm{H}_{0}$ ditolak, artinya kecerdasan spiritual berpengaruh positif dan signifikan terhadap kinerja pegawai pada Badan Narkotika Nasional Pematangsiantar. Hasil ini sejalan dengan penelitian (Fauzan, 2017), (Ginoga, 2017), (Sholiha, Milatus., H. Hadi Sunaryo., 2017), (Indriyani and Utami, 2018).

Kemudian nilai thitung pada variabel $\mathrm{X}_{2}$ 
(kecerdasan emosional) sebesar 2,404 > dari $t_{\text {tabel }}$ dengan $\mathrm{df}=\mathrm{n}-\mathrm{k}-1 \quad(26-2-1=23)$ sebesar 2,06866 atau taraf signifikansi 0,025 $<\alpha 0,05$ maka $\mathrm{H}_{0}$ ditolak, artinya kecerdasan emosional berpengaruh positif dan signifikan terhadap kinerja pegawai pada Badan Narkotika Nasional Pematangsiantar. Hasil tersebut sesuai dengan temuan (Indra Gunawan, H. Sutadji, 2014), (Syardiansah, Afriadi and Daud, 2018), (Parawitha and Gorda, 2010), (Filatrovi, Yuniawan and Kristanto, 2018).

\section{Evaluasi}

\section{Kecerdasan Spiritual pada Badan Narkotika Nasional Pematangsiantar}

Dari rekapitulasi jawaban responden mengenai kecerdasan spiritual kecerdasan yang membantu untuk memberikan makna dan pemikiran, perilaku kerja dan kegiatan, serta mampu memberikan energi yang dapat membangun kerjasama yang baik agar pegawai dapat bekerja secara optimal. Kecerdasan spiritual pada Badan Narkotika Nasional Pematangsiantar dapat dikatakan baik, dapat dilihat dari hasil kuisioner yang dibagikan kepada responden dengan nilai ratarata 3,76 dengan kriteria jawaban baik.

Namun ada beberapa aspek yang dinilai baik tetapi masih berada di bawah nilai ratarata keseluruhan, yaitu pada dimensi jalan pengasuhan untuk indikator membangun rasa saling melindungi rekan kerja berada pada rata-rata 3,12 dengan kriteria jawaban cukup baik, cara mengatasinya dengan cara membangun rasa kepedulian antar sesama pekerja dan saling mengngatkan dalam bekerja harus hati-hati termaksud bekerja diluar lapangan. Pada dimensi jalan pengetahuan dengan indikator berinisiatif mencari informasi diperoleh nilai rata-rata 3,15 dengan kriteria jawaban cukup baik, cara mengatasinya dengan cara mencari informasi dari sumber terpercaya dan memastikan kebenaran informasi tersebut.

Kemudian pada indikator terakhir bersikap ingin memahami berada pada ratarata 3,23 dengan kriteria jawaban cukup baik, cara mengatasinya dengan cara bersifat lebih terbuka dan mulai membuka diri dengan saling memahami antara rekan kerja dan saling membantu dalam hal pekerjaan jika pegawai lain kesulitan dalam melakukan tugasnnya. Selanjutnya pada dimensi jalan kepemimpinan yang penuh dengan pengabdian dengan bersikap ramah berada pada rata-rata 3,24 dengan kriteria jawaban baik, cara mengatasinya dengan cara menerapkan $3 \mathrm{~S}$ (senyum, salam, sapa). Dalam hal ini dapat dilihat bahwa kecerdasan spiritual pada Badan Narkotika Nasional Pematangsiantar sudah dikategorikan baik. Dimensi kecerdasan spiritual tersebut merupakan keterikatan yang saling berinteraksi, saling melengkapi, dan saling mendukung satu sama lainnya di dalam mencapai kinerja yang baik.

\section{Kecerdasan Emosional pada Badan Narkotika Nasional Pematangsiantar}

Berdasarkan seluruh rekapitulasi jawaban responden mengenai kecerdasan emosional merupakan kemampuan untuk mengenali perasaan diri sendiri dan orang lain, memotivasi diri untuk mengolah emosi diri sendiri dalam berhubungan dengan orang lain. Kecerdasan emosional pada Badan Narkotika Nasional Pematangsiantar dapat dikatakan baik, dapat dilihat dari analisis yang dilakukan diperoleh nilai rata-rata keseluruhan sebesar 3,78 dengan kriteria jawaban baik.

Namun ada beberapa aspek yang dinilai baik tetapi masih berada di bawah nilai ratarata keseluruhan. Pada dimensi kesadaran diri dengan indikator mengenali perasaan diri sendiri diperoleh nilai rata-rata 3,12 dengan kriteria jawaban cukup baik, cara mengatasinya dengan mengenali emosi yang ada pada diri sendiri sehingga dapat mengontrol emosi tersebut serta dapat membedakan mana kepentingan dinas dan mana kepentingan pribadi. Dan pada dimensi pengaturan diri dengan indikator mampu menangani emosi diri sendiri diperoleh nilai rata-rata 3,12 dengan kriteria jawaban cukup baik, cara mengatasinya mampu mengendalikan emosi diri sendiri dan menahan diri, jika menemukan masalah segera di atasi dan diselesaikan agar tidak membuat pekerjaan terkendala.

Indikator menyadari dampak negatif pada saat mengelola emosi berada pada ratarata 3,76 dengan kriteria jawaban baik, cara 


\section{SULTANIST: Jurnal Manajemen dan Keuangan, Vol 8 (1), 2020}

mengatasinya dengan cara selalu berfikir positif dan mengetahui bahwa emosi dapat mengganggu dan merusak suasana hati. Pada dimensi motivasi dengan indikator dorongan untuk mencapai tujuan diperoleh nilai ratarata 3,12 dengan kriteria jawaban cukup baik, cara mengatasinya dengan mengajak para pegawai refresing menghilangkan beban kerja sementara atau dengan memberi bonus gaji kepada pegawai yang dapat melaksanakan tugasnya dengan baik.

Indikator dorongan untuk mencapai kinerja yang maksimal berada pada rata-rata 3,24 dengan kriteria jawaban cukup baik, cara mengatasinya dengan memberikan dorongan dan penambahan intensif kepada pegawai yang dapat meneyelesaikan pekerjaannya dengan baik dan cepat. Indikator memiliki kemampuan dalam menghadapi kegagalan berada pada rata-rata 3,72 dengan kriteria jawaban baik, cara mengatasinya dengan melakukan pekerjaannya sebaik mungkin agar terhindar dari kegagalan kerja dengan mengerjakan tugas dan pekerjaan sebelum tenggang waktu yang ditentukan, dan lebih rapih lagi dalam menyelesaikan pekerjaannya.

Dalam hal ini dapat dilihat bahwa kecerdasan emosional pada Badan Badan Narkotika Nasional Pematangsiantar sudah dikategorikan baik. Walaupun demikian diharapkan agar pemimpin dan pegawai dapat lebih melatih dalam emosi dan pengendalian diri pada organisasi.

\section{Kepuasan Kerja Pada PT Perkebunan Nusantara III (Persero) Kebun Bangun}

Dari rekapitulasi jawaban responden mengenai kinerja pegawai merupakan salah satu hal penting dalam penilaian organisasi karena sangat menentukan keberhasilan suatu pegawai. Kinerja pegawai dilakukan secara sistematis untuk mengetahui hasil pekerjan pegawai dan kinerja instansi. Untuk meningkatkan kinerja pegawai, instansi tersebut sebaiknya melakukan penilaian kerja dan pembinaan secara formal dan membandingkan secara periodik untuk membantu dalam upaya meningkatkan kinerja pegawai. Dimensi kinerja pegawai terdiri dari sasaran kerja pegawai dan perilaku kerja dengan nilai rata-rata keseluruhan sebesar
3,89 dengan kriteria jawaban baik.

Namun ada beberapa indikator yang masih berada dibawah nilai rata-rata keseluruhan pada dimensi sasaran kerja pegawai dengan indikator penanganan volume pekerjaan yang banyak memperoleh nilai ratarata 3,76 dengan kriteria jawaban baik, cara mengatasinya dengan cara memporsir berkas satu persatu lalu menetapkan pembagiannya dan mengerjakannya dengan melihat berapa lama waktu kerja. Indikator ketepatan waktu menyelesaikan pekerjaan diperoleh dengan nilai rata-rata 3,12 dengan kriteria jawaban cukup baik, cara mengatasinya dengan menyelesaikan pekerjaannya terlebih dahulu lalu melakukan kegiatan lainnya agar tugas dapat terselesaikan tepat pada waktunya.

Indikator kesesuaian anggaran yang diberikan memperoleh nilai rata-rata 3,80 dengan kriteria jawaban baik, cara mengatasinya dengan mengonfirmasi atasan dan yang bersangkutan lainnya tentang pencairan dana agar kegiatan dapat berjalan dengan lancar.

Pada dimensi perilaku kerja dengan indikator sikap memberikan pelayanan memperoleh nilai rata-rata 3,88 dengan kriteria jawaban baik, cara mengatasinya dengan atasan menegur karyawan yang kurang baik dalam melalakukan pelayanan masyarakat. Indikator kecepatan dalam pelayanan memperoleh nilai rata-rata 3,84 dengan kriteria jawaban baik, cara mengatasinya dapat diatasi dengan menetapkan jam layanan dan waktu pengambilan berkas agar diberlakukan waktu tunggu yang tepat. Indikator tinggkat kejujuran memperoleh nilai rata-rata 3,88 dengan kriteria jawaban baik, cara mengatasinya dengan cara atasan memberikan sanksi kepada pegawai yang melakukan korupsi waktu agar mendapatkan efek jerah.

Indikator mengutamakan kepentingan dinas diatas kepentingan pribadi diperoleh rata-rata 3,12 dengan kriteria jawaban cukup baik, cara mengatasinya dengan menetapkan kebijakan yang lebih keras dari biasanya seperti memberikan sanksi kepada pegawai dan pengurangan gaji. Indikator kerja sama dengan rekan kerja memperoleh nilai rata-rata 3,80 dengan kriteria jawaban baik, cara mengatasinya dengan membangun solidaritas atara sesame pegawai dan mampu terbuka dan 
saling membangun kerja sama yang solid.

Dari evaluasi kinerja pegawai di atas dapat diambil kesimpulan apabila semua halhal sudah terlaksanakan, maka kinerja pegawai dapat ditingkatkan lagi dimana pegawai bekerja seefektif dan seefisien mungkin agar tujuan organisasi dapat tercapai dengan baik.

\section{KESIMPULAN DAN SARAN}

\section{Kesimpulan}

Hasil analisis regresi linear berganda menunjukan adanya pengaruh yang positif antara kecerdasan spiritual dan kecerdasan emosional terhadap kinerja pegawai pada Badan Narkotika Nasional Pematangsiantar. Kemudian hasil analisis koefisien korelasi menunjukan adanya hubungan yang kuat dan positif antara kecerdasan spiritual dan kecerdasan emosional terhadap kinerja pegawai pada Badan Narkotika Nasional Pematangsiantar. Kemudian baik tidaknya kinerja pegawai pada Badan Narkotika Nasional Pematangsiantar dapat dijelaskan oleh kecerdasan spiritual dan kecerdasan emosional. Untuk hasil pengujian hipotesis secara simultan dengan uji $\mathrm{F}$ menunjukan adanya pengaruh yang positif dan signifikan antara kecerdasan spiritual dan kecerdasan emosional terhadap kinerja pegawai pada Badan Narkotika Nasional Pematangsiantar. Selanjutnya hasil pengujian hipotesis secara parsial dengan uji $\mathrm{t}$ menunjukkan adanya pengaruh yang positif dan signifikan antara kecerdasan spiritual dan kecerdasan emosional terhadap kinerja pegawai pada Badan Narkotika Nasional Pematangsiantar secara parsial.

\section{Saran}

Untuk meningkatkan kecerdasan spiritual pada Badan Narkotika Nasional Pematangsiantar terdapat pada dimensi jalan pengasuhan untuk indikator membangun rasa saling melindungi rekan kerja cara mengatasinya dengan cara lebih memperhatikan sesama rekan kerja dan lebih peduli antara sesama sehingga dalam membangun rasa saling melindungi dapat diwujudkan. Dimensi kesadaran diri dengan indikator mengenali perasaan diri sendiri, cara mengatasinya dengan mengenali emosi yang ada pada diri sendiri sehingga dapat mengontrol emosi tersebut serta dapat membedakan mana kepentingan dinas dan mana kepentingan pribadi. Dan pada dimensi pengaturan diri dengan indikator mampu menangani emosi diri sendiri cara mengatasinya mampu mengendalikan emosi diri sendiri dan menahan diri, jika menemukan masalah segera di atasi dan diselesaikan agar tidak membuat pekerjaan terkendala. Dan pada dimensi motivasi dengan indikator dorongan mencapai tujuan, cara mengatasinya dengan mengajak para pegawai refresing menghilangkan beban kerja atau dengan memberikan bonus gaji kepada pegawai yang dapat melaksanakan tugasnya degan baik. Kemudian untuk meningkatkan kinerja pegawai pada Badan Narkotika Nasional Pematangsiantar terdapat pada dimensi sasaran kerja pegawai dengan Indikator ketepatan waktu menyelesaikan pekerjaan dengan kriteria jawaban cukup baik, cara mengatasinya dengan menyelesaikan pekerjaannya terlebih dahulu lalu melakukan kegiatan lainnya agar tugas dapat terselesaikan tepat pada waktunya.

\section{DAFTAR PUSTAKA}

Agustian, Ary Ginanjar. 2001. Kecerdasan ESQ berdasarkan 6 Rukun Iman dan 5 Rukun Islam. Jakarta: Penerbit Mirzan.

Bangun, Wilson. 2012. Manajemen Sumber Daya Manusia. Jakarta: Penerbit Erlangga. Fauzan, M. F. A. (2017) 'Pengaruh Kecerdasan Emosional , Kecerdasan Spiritual, Dan Tekanan Klien Terhadap Kualitas Audit', Jurnal Profita, 7(2), pp. 1-19.

Filatrovi, E. W., Yuniawan, A. and Kristanto, R. S. (2018) 'Pengaruh Kecerdasan Emosional, Kepemimpinan Pelayan (Servant Leadership) dan Kepuasan Kerja Terhadap Kinerja Pada Dosen Sekolah Tinggi Ilmu Ekonomi di Kota Semarang', Jurnal Ilmiah Administrasi Bisnis dan Inovasi, 2(1). doi: 10.25139/jai.v2i1.1148.

Ginoga, V. (2017) 'Pengaruh Budaya 
Organisasi, Kecerdasan Spiritual dan Motivasi terhadap Kinerja dan Kepuasan Kerja Karyawan pada PT PELINDO IV (Persero) di Makassar', JABE (Journal of Applied Business and Economic), 4(1), p. 66. doi: 10.30998/jabe.v4i1.1907.

Goleman, D. 2005. Kecerdasan Emosional; Mengapa EI Lebih Penting Dari Pada $I Q$. Jakarta: Gramedia Pustaka Utama.

Indra Gunawan, H. Sutadji, E. R. (2014) 'Pengaruh Kecerdasan Emosional Dan Komitmen Organisasi Terhadap Kinerja Pegawai Dinas Perkebunan Dan Kehutanan Kabupaten Kutai Kartanegara', eJournal Administrative Reform, 2(2), p. 13. Available at: ar.mian.fisip-unmul.ac.id\%0D.

Indriyani, D. S. and Utami, H. N. (2018)

'Pengaruh Kecerdasan Emosional dan Kecerdasan Spiritual Terhadap Kinerja Karyawan (Studi pada Karyawan PT. Industri Kereta Api (Persero) MadiunJawa Timur', Jurnal Administrasi Bisnis, 59(1), pp. 41-50. Available at: http://administrasibisnis.studentjournal.ub .ac.id/index.php/jab/article/view/2453

Khavari. 2004. The Art Of Happiness. Jakarta: Mirzan Pustaka.

Mangkunegara, A. A. Anwar Prabu. 2015. Manajemen Sumber Daya Manusia Perusahaan. Bandung. PT Remaja Rosdakarya.

Mathis, Robert L. dan John H. Jackson. 2006. Human Resource Management (Manajemen Sumber Daya Manusia). Edisi Kesepuluh. Jakarta: Salemba Empat.

Parawitha, G. A. and Gorda, E. S. (2010) 'Pengaruh Kecerdasan Spiritual, Kecerdasan Emosional, Kepemimpinan Transformasional Terhadap Kepuasan Kerja dan Kinerja', Jurnal Ilmiah Manajemen dan Bisnis, 2(2), pp. 135143.

Robbins, Stephen P. dan Timothy A. Judge. 2009. Perilaku Organisasi. Edisi Keduabelas. Jakarta: Salemba Empat.

Sholiha, Milatus., H. Hadi Sunaryo., A. A. P. (2017) 'Pengaruh Kecerdasan Emosional Dan Kecerdasan Spiritual
Terhadap Kinerja Guru SMP An-Nur Bululawang-Malang', Warta Ekonomi, 7(17), pp. 78-92.

Syardiansah, S., Afriadi, A. and Daud, M. N. (2018) 'Analisis Pengaruh Kecerdasan Emosional dan Kecerdasan Spiritual Terhadap Kinerja Karyawan Perusahaan Daerah Air Minum Tirta Peusada', Jupiis: Jurnal Pendidikan Ilmu-Ilmu Sosial, 10(2), p. 182. doi: 10.24114/jupiis.v10i2.11142.

Zohar, Danah dan Ian Marshall. 2000. SQ: Kecerdasan Spiritual. Cetakan ke tujuh. Bandung: Mizan.

\section{Profil Singkat}

Aufiar Riesvi, Lahir di Pematangsiantar, tanggal 21 Febuari 1997, lulus dari jurusan Sarjana Manajemen Sekolah Tinggi Ilmu Ekonomi Sultan Agung pada tahun 2019. Darwin Lie, Gelar doktor diperoleh dari Universitas Pasundan Bandung dengan konsentrasi ilmu manajemen dan lulus pada tahun 2018. Efendi, gelar magister manajemen diperoleh dari Program Magister Manajemen Fakultas Pascasarjana Universitas HKBP Nommensen Medan dan lulus pada tahun 2012. Gelar doktor diperoleh dari Universitas Pasundan Bandung dengan konsentrasi ilmu manajemen dan lulus pada tahun 2018. Sherly, gelar magister manajemen diperoleh dari Program Magister Manajemen Fakultas Pascasarjana Universitas HKBP Nommensen Medan dan lulus pada tahun 2014. 